\title{
CÁRIE - uma doença que pode ser evitada
}

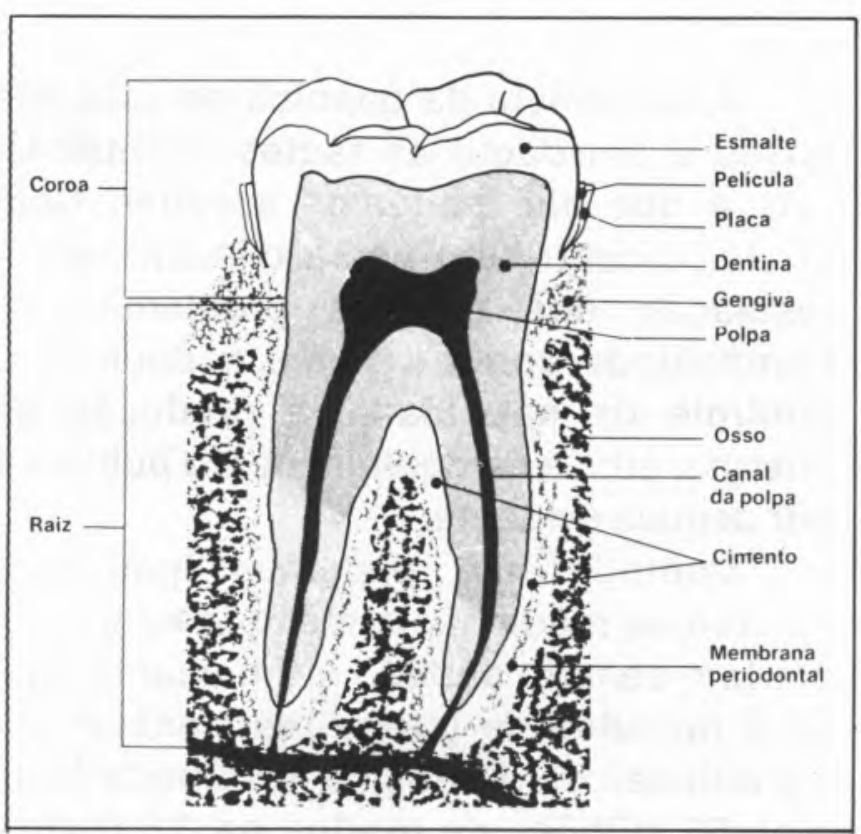

Esta seccão de um molar humano mostra depositos de pelicula e de placa proximo da linha da gengiva

Num dos laboratórios que dirige, na divisão de odontologia preventiva da Universidade de Colúmbia, o Dr. Irwin D. Mandel fala acerca dos actuais conhecimentos sobre as causas da cárie. "Actualmente - diz ele - compreendemos bem os mecanismos globais envolvidos. Os cientistas dentários agora dedicam-se principalmente-ao estudo dos pormenores. Deste modo esperam poder localizar as etapas exactas do processo em que possam combater eficazmente os estragos causados por esta doença.n

Presentemente os cientistas estão a estudar o modo como as bactérias envolvidas na cárie podem ser inactivadas ou des. truidas. Estão a investigar os papéis desempenhados pela dieta, pela saliva, pela composição do esmalte e pelas substân. cias quimicas que permitem às bactérias aderirem aos dentes. Estão também a testar novos processos para combater a cárie, entre os quais se contam as vacinas, os anti-sépticos e as resinas ("sealants").

A necessidade de métodos mais eficazes para combater a cárie é por de mais evidente. De facto, trata-se de uma doença mais vulgar do que a gripe comum e todos os anos se gastam somas elevadissimas nos dentistas. Mas os prejuizos causados pela cárie não são apenas financeiros. A cárie pode causar dores excruciantes e requer longas horas nos consultórios dentários, em particular, se conduz à perda de dentes, pode implicar diminuição da capacidade de mastigação e de fala, alterações na aparência e bem-estar geral.

$A$ idade é o principal factor na determinação da vulnerabilidade de um individuo à cárie. A cárie é a principal causa da perda de dentes antes dos 35 anos. Depois dessa idade, a causa principal da perda de dentes é a doença periodontal, que ataca as gengivas, o tecido conectivo e os ossos que rodeiam e suportam os dentes.

A medida que envelhecem, os dentes tornam-se mais resis. tentes à cárie. Crê-se que isso se deve, em parte, ao aumento da quantidade de fluor no esmalte. Os dentes mais velhos também
Traduzido e adaptado de "Tooth Decay", Howard J. Sanders, in Chem. \& Eng. News, 1980, 58 (8), 30-42, por M.J.O. Baptista

Os cientistas estão a desenvolver muitos processos inovadores para prevenção da cárie, em vez de se limitarem a reparar os estragos por ela causados!

podem apresentar menos cavidades devido às áreas dentais mais susceptiveis já estarem protegidas por reconstruções.

Nos últimos trinta anos tem-se vindo a assistir a uma mudança básica na ênfase posta na pesquisa pela profissão dentária. Anteriormente o interesse centrava-se à volta da reconstrução e substituição dos dentes. Os pesquisadores preocupavam-se principalmente com problemas tais como o desenvolvimento de melhores produtos para reconstruções, dentaduras e coroas. Actualmente dão muito mais atenção à prevenção da cárie. Uma tal prevenção, é claro, requer um conhecimento muito maior dos factores subjacentes envolvidos no processo da cárie.

0 apoio financeiro relativamente reduzido concedido à pesquisa no dominio da cárie reflecte a relativa indiferença da opinião pública em relação às doenças dentárias. As pessoas não se preocupam com a cárie do mesmo modo que se preocupam com o cancro ou as doenças cardiacas. Por um lado, ninguém morre de cárie, por outro, muitas pessoas aceitam-na como uma doença inevitável.

Porque a cárie não constitui uma ameaça à vida nem è capaz de causar incapacidade grave, não se trata de uma doença especialmente dramática.

\section{DESMINERALIZAÇÃO DO ESMALTE}

O que é, de facto, a cárie? Trata-se da desmineralização localizada do esmalte dental e em geral também da dentina, que conduz eventualmente à formação de uma cavidade. Esta desmineralizaão é causada por ácidos orgânicos que penetram a superficie do esmalte. Por seu lado, estes ácidos são formados pela acção de bactérias especificas sobre açúcares e outros carbohidratos fermentáveis presentes na placa aderente aos dentes.

Como aponta Walter E. Brown, director da American Dental Association's Health Foundation Research Unit do National 
Bureau of Standards (NBS), "Nos últimos cinco anos, os progressos feitos na pesquisa dentária ocorrem em muitas pequenas etapas que gradualmente estão a conduzir a uma melhor compreensão do processo da cárie e de como ele pode ser inibido ou invertido. Obviamente fizeram-se importantes progressos, mesmo sem ter havido descobertas espectaculares."

\section{Os progressos mais importantes incluem:}

- Uso de bactérias mortas para imunizar animais de labo ratório contra os microrganismos envolvidos na cárie.

- Pesquisa de uma vacina anticárie que combata um enzima necessário à formação da placa dentária.

- Melhor conhecimento de como o anticorpo secretor de imunoglobulina A protege os dentes contra a cárie.

- Melhor compreensão de como actuam as proteinas antibacterianas não-imunológicas da saliva.

- Mais informações sobre as bactérias que colonizam os dentes.

- Crescente compreensão sobre o modo como as bactérias aderem aos dentes.

- Mais pormenores sobre como é que os dentes são des. mineralizados.

- Desenvolvimento de novos processos de aplicar fluoreto para protecção dos dentes.

- Investigação de vestigios metálicos que possam retardar a cárie.

A região dos dentes que maior interesse tem em cárie dentária é o esmalte, a camada exterior dos dentes acima das gengivas. Consiste em cerca de $98 \%$ de matéria inorgānica (incluindo água) e $2 \%$ de matéria orgânica, e é a subsistância mais dura do corpo humano.

Sob o esmalte encontra-se a dentina, que contém cerca de $70 \%$ de matéria iorgânica e $30 \%$ de matéria orgânica, e que se estende praticamente a todo o comprimento do dente. $\mathrm{Na}$ região mais interna do dente encontra-se a polpa, que contém nervos, vasos sanguineos e tecido fibroso.
Estando o esmalte em contacto directo com as particulas dos alimentos, as bactérias e a saliva, é essa a parte do dente que é primeiramente atacada pela cárie. $O$ processo envolve a remocão de parte do conteúdo mineral do esmalte. O mineral encontra-se principalmente sob a forma de prismas, cada um consistindo de biliōes de pequenissimos cristais de um derivado do fosfato de cálcio, a hidroxiapatite, $\mathrm{Ca}_{10}\left(\mathrm{PO}_{4}\right)_{6}(\mathrm{OH})_{2}$, que forma a estrutura cristalina do osso. A hidroxiapatite mine. ral também contém pequenas quantidades de fluoreto, carbo. nato e magnésio.

A matéria orgânica do esmalte é principalmente proteina, como a eukeratina. Durante o processo de cárie, alguma desta matéria orgânica é destruida por enzimas capazes de hidrolizar as proteinas que se encontram na placa bacteriana. Laurence C. Chow, cientista-chefe da divisão de quimica dentária da American Dental Association's Health Foundation Research Unit do NBS, faz notar que «a degradação de proteina dentária é em geral considerada como sendo relativamente insignificante na cárie. No entanto, algumas pessoas defendem que a degradação deste material proteico é importante porque destrói a matriz que mantém juntos os cristais do esmalte."

A não ser que um dente tenha sido escrupulosamente limpo, as colónias de bactérias crescem em locais especificos da sua superficie, particularmente junto à linha da gengiva. Estas colónias fazem parte da placa dental, que consiste em cerca de $70 \%$ de bactérias; o resto da placa é constituido por produtos bacterianos (polissacaridos, enzimas, ácidos) e com. ponentes da saliva.

A placa é uma substância branca ou esbranquiçada, de espessura variável. Bactérias especificas na placa formam os polissacaridos que permitem a estes microrganismos pegarem. se aos dentes e uns aos outros. Certas bactérias também convertem açúcares e outros carbohidratos fermentáveis na placa em ácidos orgânicos que provocam a cárie.

Em $1897 \mathrm{~J}$. Leon Williams, um dentista americano, descre veu pela primeira vez a presença de placa dental no esmalte. Concluiu que a placa tende a manter uma concentração relativamente elevada de ácido na superficie do esmalte inibindo a sua diluição e a neutralização pela saliva.

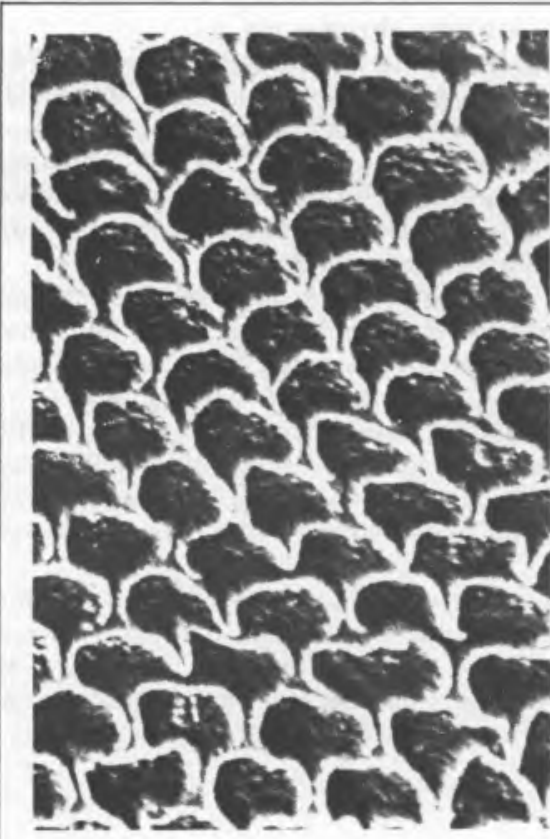

Esta micrografia electronica de esmalte humano tratado com acido mostra a estrutura prismatica tipica do esmalte dental

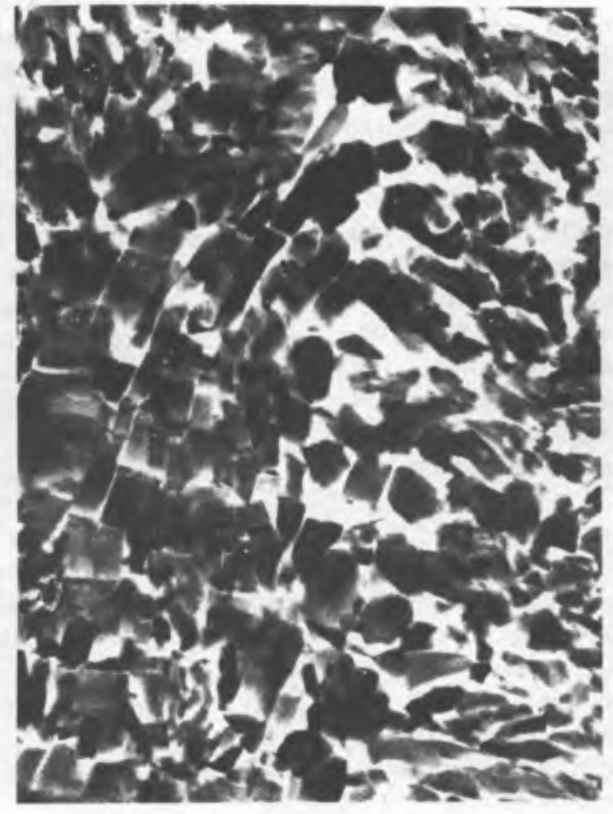

Microgralia electronica de transmissào de esmalte humano mostrando cristais de hidroxiapatite. A amplifica cao e muito superior a da fotografia da esquerd

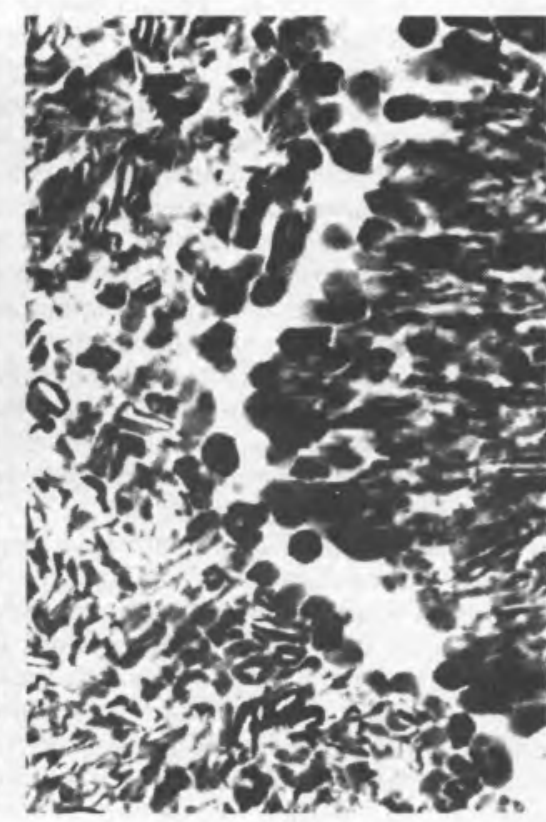

Esmalte humano em decomposicāo. $\mathrm{Na}$ area livre, os cristais de hidroxiapatite foram dissolvidos por acido 


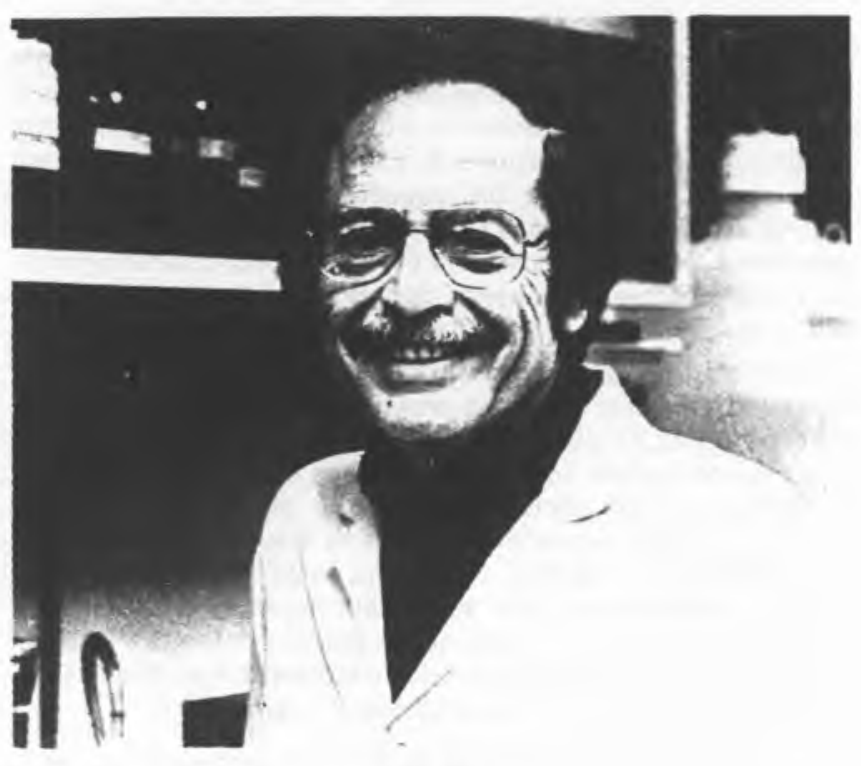

MANDELL

\section{AS BACTÉRIAS E A CÁRIE}

Durante muitos anos debateu-se acesamente se as bactérias estão, de facto, envolvidas na cárie. E se assim è, que bactèrias?

Em 1890, Willoughby D. Miller, um dentista americano então a trabalhar na Universidade de Berlim, descreveu que as bactérias são essenciais para a càrie, porque convertem os acúcares e outros carbohidratos fermentáveis em ácidos capazes de destruir o esmalte. Embora Miller nāo tenha identificado esssas bactérias, nem apreciado a importância da placa na cárie, um dos mais eminentes cientistas dentários afirma que as suas contribuiçōes uabriram o caminho para a era moderna da pesquisa sobre a càrie.n

Em 1924, J. K. Clarke, no Hospital de St. Mary em Londres, descreveu que o tipo de bactérias mais frequentemente encontradas nas cavidades dentais humanas e mais provavelmente capaz de causar cárie era aquele que designou por Streptococcus mutans. Clarke escolheu esta designaçāo por os segmentos da bactéria poderem mudar de uma forma esférica para uma forma em bastāo.

No entanto, os pontos de vista de Clarke depararam com uma quase completa indiferença porque a opiniāo então prevalecente, e que se manteve por mais alguns anos, era a de que a cárie era principalmente causada pelo Lactobacillus acidophilus e outros Lactobacilos que, a partir de açúcares, produzem ácido láctico capaz de destruir o esmalte.

Hoje em dia os cientistas crêem que os Lactobacilos apenas desempenham um papel menor na cárie. Uma das razōes è que estas bactérias, ao contrário do S. mutans, não produzem uma substância pegajosa que lhes permita aderirem às superficies lisas dos dentes. Além disso, os Lactobacilos apenas constituem uma percentagem muito pequena das bactèrias presentes na placa dental.

Importante apoio a favor da tese segundo a qual são as bactérias que causam a cárie surgiu em 1954, do trabalho de pesquisa de Frank J. Orland e colaboradores, da Universidade de Chicago. Descobriram que ratos assépticos, quando infectados com um Enterococcus e alimentados com uma dieta rica em açúcar, desenvolviam cavidades nos dentes. No entanto, outros ratos assépticos alimentados com a mesma dieta, mas não infectados com a bactéria, não apresentavam cavidades nos dentes. Trabalhos subsequentes com ratos assépticos demonstrou que o $\mathrm{S}$. mutans era um dos mais virulentos organismos produtores de cárie. Ernest Newbrun, professor de biologia oral na Universidade da Califórnia, Sāo Francisco, afirma "Esta descoberta marcou uma nova era na pesquisa sobre a cárie.n
Em 1960, Robert J. Fitzgerald, entāo no NIDR e actualmente no Veterans Administration Hospital de Miami, e Paul $\mathrm{H}$. Keys do NIDR, demonstraram a natureza infecciosa da cárie. Mostraram que Streptococci causadores de cárie, como o S. mutans, podem ser transmitidos por um hamster-fêmea à sua ninhada ou por animais infectados a outros nāo infectados que partilhem a mesma gaiola.

O S. mutans possui um certo número de propriedades que o tornam particularmente virulento como promotor de cárie:

- Contém o enzima lacticodesidrogenase, que converte o ácido pirúvico (um produto da degradaçāo da sacarose) em ácido láctico. Por seu turno, o ácido láctico desmineraliza o esmalte dos dentes.

- Contèm o enzima glucosiltransferase, que polimeriza a glucose, obtida da sacarose, para dar glucanos. Estes polissacaridos extracelulares são substâncias extremamente pegajosas que permitem ao $\mathrm{S}$. mutans e a outras bactérias aderirem umas às outras e acumularem-se nos dentes, especialmente nas superficies lisas do esmalte.

- Forma colónias facilmente nas superficies dos dentes. Estas colónias, juntamente com os glucanos, são os principais componentes da placa.

- Produz mais ácido do que outros Streptococci.

- Pode sobreviver num meio de baixo pH.

- Pode formar, a partir de açucares, polissacaridos intracelulares do tipo amilopectina. Estes sāo armazenados nas células e depois convertidos em àcido.

O crescimento do $\mathrm{S}$. mutans requer que na boca existam superficies sólidas, quer dentes, quer dentaduras. Por exemplo, na boca das crianças nāo se encontra $S$. mutans até que os seus dentes tenham nascido. As bactérias não podem formar colónias nas membranas mucosas da boca porque não podem aderir a elas.

Que o S. mutans produz glucanos a partir de glucose derivada da sacarose foi demonstrado em hamsters por Fitzgerald e Keys em 1960, no NIDR. Verificaram eles que os glucanos desempenham um papel importante na produçāo da placa e portanto na promoção da cárie.

Por outro lado, os glucanos inibem (mas nâo impedem) a capacidade da saliva para remover as bactérias da superficie dos dentes. Os glucanos também reduzem a tendēncia da saliva para remover o ácido formado na placa.

Variam as estimativas quanto à importância relativa do $\mathrm{S}$. mutans como causa da cárie em seres humanos. Ronald J. Gibbons, director do departamento de microbiologia do Centro Dentário Forsyth de Boston, afirma que o S. mutans pode ser isolado de 90 a $95 \%$ das cavidades do esmalte humano. Calcula ele que esta bactéria está envolvida na formação de cerca de $90 \%$ das cavidades dentais em seres humanos.

"Dados recentes - afirma Gibbons - tendem a confirmar a extraordinária importância do S. mutans. Estudos feitos em macacos, por exemplo, mostram que estes desenvolvem muito poucas cavidades se na sua boca nāo existir esta bactéria.n

Muita controvérsia rodeia a questāo de que outras bacté. rias, para além do $\mathrm{S}$. mutans, estāo envolvidas na cárie. Entre as mais provaveis contam-se outros Streptococci, como o S. san guis e o S. mitis. Outras possibilidades são o Lactobacillus casei e o Actinomyces viscosus.

Estes organismos exercem a sua acção em pontos particulares dos dentes. Vários Lactobacilli tendem a causar cáries nas concavidades e fissuras dos molares. Diversos Actinomyces atacam as raizes dos dentes. Vários Streptococci atacam as superficies lisas e outras partes dos dentes.

\section{ALIMENTOS PARA AS BACTÉRIAS}

Para sobreviver obviamente as bactérias necessitam de alimentos. Ratos que têm bactèrias causadoras de cáries orais mas que sāo alimentados com soluçōes de açúcar ministradas por um tubo directamente para o estōmago não desenvolvem cavidades. 
As principais fontes de açúcar na dieta incluem bebidas refrigerantes, rebuçados, bolos, sorvetes e cereais pré-açucarados.

O papel primordial do açúcar como causa da cárie tem šido demonstrado em muitos estudos epidemológicos. Por exemplo, os esquimós que vivem no seu ambiente natural praticamente não têm cáries, porque a sua dieta consiste quase inteiramente de proteinas e gorduras animais. Quando os esquimós passam a ter uma dieta do tipo ocidental, repleta de consideráveis quantidades de açúcar, aumenta abruptamente a incidência da cárie.

Em geral o amido nāo é considerado como causa significativa da cárie porque a sua conversảo em açúcar, pelo enzima amilase, é excessivamente lenta para que muito açúcar possa ser convertido na boca.

Os alimentos variam consideravelmente quanto à sua tendência para promover a cárie. Frutos como as maçās, que contêm mais de $10 \%$ de carbohidrato fermentável, tendem a promover a cárie. Ao contrário da crença popular, as maçās nâo removem a placa ou limpam os dentes, aumentando, sim, o conteúdo de açúcar indesejável na placa. "Assim, e ao contrário daquilo que se tem pensado durante muitos anos - diz Leon M. Silverstone, director da divisäo de cariologia da Universidade de lowa - terminar uma refeição com uma maçā não é uma maneira eficiente de impedir a cárie.n

O que é importante, em termos do potencial causador de cárie de um alimento, nảo é só a quantidade de açúcar que contém, mas tambèm o espaço de tempo durante o qual esse alimento permanece na boca. $O$ acúcar sob a forma de caramelos, que se pegam aos dentes, é mais perigoso do que a mesma quantidade de açúcar num refrigerante, que apenas permanece na boca durante pouco tempo.

Também é importante a frequência com que se come o açúcar. De acordo com um estudo realizado por cientistas escandinavos, as pessoas que num ano consomem, em média, $70 \mathrm{~kg}$ de açúcar às refeiçōes e $15 \mathrm{~kg}$ entre as refeiçōes desenvolvem mais cavidades do que aquelas que consomem $94 \mathrm{~kg}$ de açúcar exclusivamente às refeiçōes.

\section{O esmalte perde os iões cálcio e fosfato a $\mathrm{pH}$ inferior a 5,5}

$\mathrm{pH}$

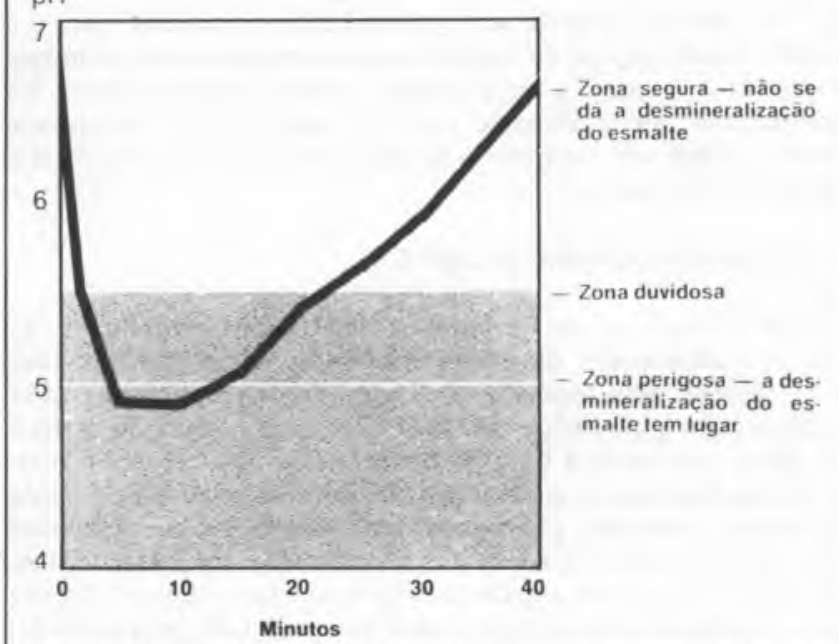

Esta curva, desenvolvida por R. M. Stephan do NIDR, mostra como o pH da placa se altera depois de bochechar com uma solucảo de glucose

O ácido principal causador da cárie é o ácido láctico, o principal ácido formado pela degradaçāo da sacarose. Alèm disso, o ácido láctico é o ácido mais forte que se forma por fermentação de açücares.

Outros ácidos orgânicos que também decompōem o esmalte incluem (por ordem decrescente de iões hidrogénio disponi- veis, e portanto por ordem decrescente de torça ácida) os ácidos fórmico, succinico, butirico, acético e propiónico. Estes ácidos, que sāo produzidos em muito menores quantidades que o ácido láctico, sāo formados como parte do processo metabó. lico das bactérias da placa.

Quando estes ácidos fazem com que o $\mathrm{pH}$ da placa desça para 5,5 ou menos, podem causar uma lenta desmineralizaçăo do esmalte por perda de iões cálcio e fosfato. Quando se lava a boca com uma soluçāo de glucose, cerca de dois minutos depois o $\mathrm{pH}$ da placa desce de cerca de 6,8 para 5,5 ou valores inferiores. $\mathrm{O} \mathrm{pH}$ mantém-se nesta "zona de perigo" durante cerca de 20 minutos. $\mathrm{O}$ pH aumenta então para 6,0 ou mais, cessando a desmineralização. Finalmente após cerca de 40 minutos a placa volta ao seu $\mathrm{pH}$ original de 6,8 .

A saliva, uma soluçāo extremamente complexa que, entre outras funçōes, lubrifica os alimentos ingeridos e inicia a de. composição dos amidos, desempenha um papel critico no processo de cárie. Quando sāo removidas as glândulas saliva. res de ratos, aumenta substancialmente a sua susceptibilidade à cárie. Nas pessoas cujas glândulas salivares foram expostas a radiaçāo durante tratamento a cancro da cabeça ou do pes. coço, geralmente observa-se uma evolução rápida e aguda da cárie.

A saliva ajuda a reduzir a cárie pois lava da superficie dos dentes as particulas dos alimentos, as bactérias e os ácidos. Actua também como um tampão quimico, que reduz a extensāo do decréscimo do $\mathrm{pH}$ da placa por acção dos ácidos. $\mathrm{O}$ mais importante tampão salivar é a mistura de ião bicarbonato $\left(\mathrm{HCO}_{3}\right)$ e de ácido carbónico $\left(\mathrm{H}_{2} \mathrm{CO}_{3}\right)$, que tende a neutralizar parcialmente os ácidos causadores de cárie que são produzidos na placa.

Outro componente da saliva è a ureia. As bactérias da placa podem converter este composto em amoniaco, o qual também neutraliza alguns dos ácidos da placa.

Em 1972, Israel Kleinberg, presentemente na Universidade Estadual de Nova IOrque, Stony Brook, isolou da saliva um te. trapeptido (glicina-glicina-lisina-arginina) a que chamou sialina. Este composto pode ser metabolizado por diversos microrganismos da placa para formar amoniaco. No entanto, não está ainda esclarecido se suficiente sialina se pode difundir através da placa humana para ser eficiente na neutralização de ácidos por meio de amoniaco libertado.

A saliva contém a proteina lactoferrina. Esta è capaz de se complexar com dois átomos de ferro por molécula, podendo remover o ião férrico de que algumas bactérias necessitam para o seu metabolismo. Em consequência é inibido o crescimento dessas bactérias. Um grupo de pesquisadores descreveu que a lactoferrina pode destruir o S. mutans, podendo portanto ser útil no controlo da cárie.

Entre os muitos outros componentes da saliva encontramse os iōes cálcio e fosfato. Depositados no esmalte como fosfato de cálcio durante os estádios iniciais do desenvolvimento de uma cavidade, podem reparar cáries de menor importância.

Investigação crescente centra-se actualmente numa fina camada orgânica, a pelicula, situada entre o esmalte e a placa. A pelicula, com cerca de 0,1 a 1 micron de espessura, é formada quando as proteinas da saliva são selectivamente adsorvidas no esmalte, e crê-se que desempenha diversas funções impor tantes na cárie. A pelicula promove a ligação das bactérias à superficie do esmalte, influencia o transporte de ácidos para o esmalte e a difusão de iões cálcio e fosfato para fora do esmalte.

Irwin D. Mandel, da Universidade de Colúmbia, afirma que "O papel potencialmente protector desta barreira difusora ou modificador só agora começa a ser apreciado. A modificaçāo da pelicula pode ter um profundo impacto na desmineralização dos dentes.n

John W. Hein, director do Centro Dentário Forsyth, diz que "Quando soubermos mais sobre quais são as proteinas exis. tentes na pelicula, seremos capazes de as modificar de modo a que já näo possam atrair bactérias.” 


\section{Bactérias convertem sucrose em ácido láctico, que ataca o esmalte dental}

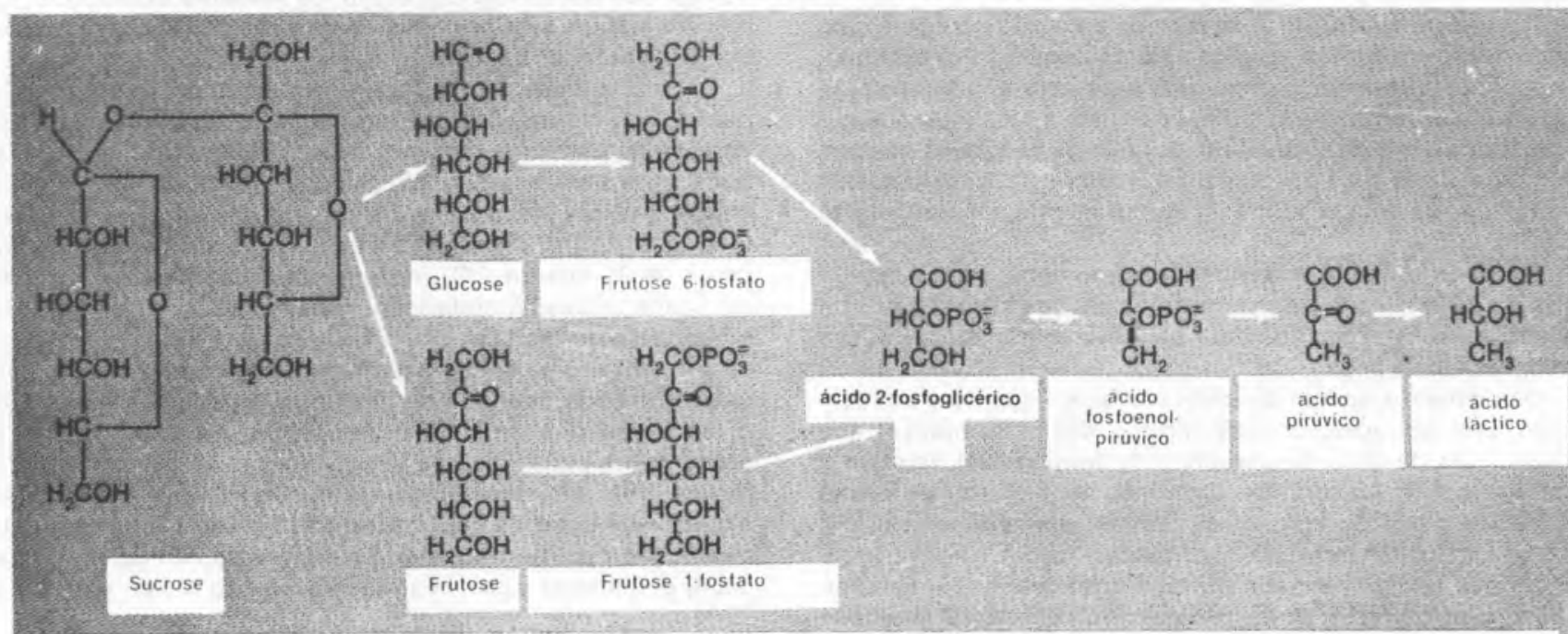

A sucrose è decomposta primeiro em glucose e frutose. Por meio de uma série de reaccôes, estes compostos sảo convertidos em àcido láctico, o ácido mais forte que se forma durante a fermentação dos açúcares

Dos 32 dentes permanentes da boca, os molares são especialmente susceptiveis à cárie porque apresentam concavida des e fissureas que tendem a acumular particulas de alimentos que muitas vezes sāo dificeis de remover.

A cárie requer a existência simultânea de três factores principais:

- Dentes susceptiveis à cárie.

- Bactérias que podem causar cárie

- Alimentos que, quando actuados pelas bactérias, formam ácidos.

A vulnerabilidade dos dentes à cárie depende do seu con teúdo em certos iōes, como o iāo fluoreto. Depende também do espaçamento e forma dos dentes e portanto da tendência das particulas dos alimentos para se acumularem neles ou entre eles.

As cavidades dos dentes formam-se quando os ácidos decompõem a hidroxiapatite do esmalte, de acordo com a seguinte equação:

$\mathrm{Ca}_{10}\left(\mathrm{PO}_{4}\right)_{6}(\mathrm{OH})_{2}+8 \mathrm{H}^{+}$ $-10 \mathrm{Ca}+++6 \mathrm{HPO}_{4}^{=}+2 \mathrm{H}_{2} \mathrm{O}$

Os iōes cálcio e fosfato difundem-se dos dentes e são levados pela saliva.

Embora possa parecer estranho, a cárie inicia-se sob a superficie do esmalte, em vez de à sua superficie, apesar de o ácido que a causa se formar na placa que cobre o dente.

Uma explicação para este facto è que o ião fluoreto (da água potável, dos alimentos de dentífricos ou de outras fontes) pode reagir com a hidroxiapatite para formar fluorapatite. Este composto está presente em maior concentra. ção à superficie do esmalte (os 60 micrometros exteriores contêm cerca de 10 vezes mais fluoreto do que a camada interna do esmalte). A fluorapatite é muito mais resistente ao ataque pelos ácidos do que a hidroxiapatite. Assim, quando os ácidos penetram o esmalte através de poros minúsculos, desmineralizam o interior e deixam essencialmente intacto o esmalte mais resistente da superficie. $O$ resultado é a formação de uma área desmineralizada sob a superficie do esmalte, a qual se apresenta como uma mancha branca opaca.

Uma outra teoria, proposta em 1974 por Edgard C. Moreno e colaboradores, do Centro Dentário Forsyth, e agora largamente aceite, é que, embora os ácidos ataquem a superficie do esmalte, este é reconstituido nesse local, quase tão rapidamente como se dissolve, por reprecipitação de iōes cálcio e fosfato difundidos da regiâo interna do esmalte. Como faz notar Edgard Moreno, "A superficie do esmalte parece inalterada durante este processo simplesmente porque è continuamente regenerada.,

Moreno crê também que os ácidos se difundem para a zona mais interna do esmalte, onde produzem uma zona desmineralizada ou mancha branca. Gradualmente esta zona subsuperficial torna-se tão grande e a superficie adjacente do esmalte tāo fina, que a camada superficial se quebra para formar uma cavidade exposta. Estas cavidades levam em geral cerca de 12 a 24 meses a desenvolver-se. Uma vez formadas, as bactérias podem invadir o interior do esmalte e acelerar a sua desintegração.

Se a cavidade não for obturada, a cárie geralmente continua através do esmalte e para a dentina. Quando eventual. mente a cárie atinge a polpa do dente (o "nervon) surgem dores agudas.

No estudo da cárie, um método de considerável valor é. o exame microscópico de especimens de esmalte com luz polarizada. Uma vez que a luz polarizada produz diferenças de cor acentuadas, as regiōes de esmalte parcialmente desmineralizado podem ser facilmente distinguidas das áreas em que o esmalte está intacto.

\section{O COMBATE CONTRA A CÁRIE}

Enquanto muitos cientistas dentários investigam as causas subjacentes da cárie, outros preocupam-se em lutar para vencer esta doença. O Programa Nacional de Cárie estabelecido pelo NIDR em 1971 propunha quatro objectivos fundamentais na sua batalha contra a cárie - aumentar a re sistência dos dentes à cárie (principalmente através do uso de fluoreto); encontrar processos para combater as bactérias causadoras da cárie; encorajar a mudanças na dieta, tornan do-a menos capaz de causar cárie; e aumentar a disponibilidade dos métodos preventivos da cárie e sua aceitação pelo público.

A descoberta da eficácia do fluoreto na redução da cárie é geralmente aceite nos circulos cientificos como o maior progresso realizado no campo da prevençāo da cárie neste século. Irwin D. Mandel, da Universidade de Colúmbia, afirma que "Desde há alguns anos, os fluoretos têm sido o meio mais eficaz de prevençāo da cárie.n

Newbrun, da Universidade da Califórnia, Sāo Francisco, diz, "Quando submetidas a cuidadoso escrutínio cientifico, tem-se consistentemente provado serem infundadas as reclamaçōes contra o uso do fluoreto... O tratamento da água com sais contendo fluoreto tem sido largamente aceite com 
seguro e eficaz na redução da cárie por todas as pessoas ligadas aos problemas da saúde (médicos, epidemiologistas, toxicólogos e organismos de saúde públicos, e não apenas pelos dentistas).n

A utilização de água potável tratada com fluoreto resulta de uma descoberta feita em 1916 por Frederick S. McKay, um jovem dentista de Colorado Springs, no Colorado. McKay concluiu que o aparecimento de manchas ou descoloração do es. malte dos dentes que observou em muitos dos seus pacientes era causado por alguma substância presente na água que bebiam, e observou também que as pessoas cujos dentes apre. sentavam essas manchas tinham muito poucas cavidades.

No entanto, só em 1931 è que Harry V. Churchill, um quimico analitico da Aluminium Co. of America, identificou essa substância como sendo fluoreto em concentraçōes elevadas.

Em 1938 os cientistas descobriram que no esmalte surgem machas apreciáveis quando a água potável contém $2 \mathrm{ppm}$ ou mais de fluoreto. Quando a água contém apenas $1 \mathrm{ppm}$ de fluo reto, as manchas não surgem no esmalte, mas são muito redu. zidas as novas cáries.

tm 1942, H. I rendley Dean e colaboradores, do Serviço de Saúde Pública dos Estados Unidos, descobriram que as crianças vivendo em comunidades cuja água potável continha $1 \mathrm{ppm}$ de fluoreto desenvolviam cerca de $60 \%$ menos cavidades do que aquelas que consumiam água potável contendo fluoreto em concentraçôes muito inferiores. Foi em 1945, em Grand Rapids, Michigan, que pela primeira vez se procedeu ao tratamento com fluoreto da água potável de uma cidade para determinação do seu efeito sobre a cárie; a água foi tratada com fluoreto de sódio para elevar para $1 \mathrm{ppm}$ o seu conteúdo em fluoreto.

Os defensores do tratamento da água potável com fluoreto apontam as suas numerosas vantagens. Por exemplo, as crianças que bebem água fluoretada apresentam cerca de 50 a $60 \%$ menos cavidades do que as que não bebem água contendo fluoreto. De acordo com um estudo feito, o

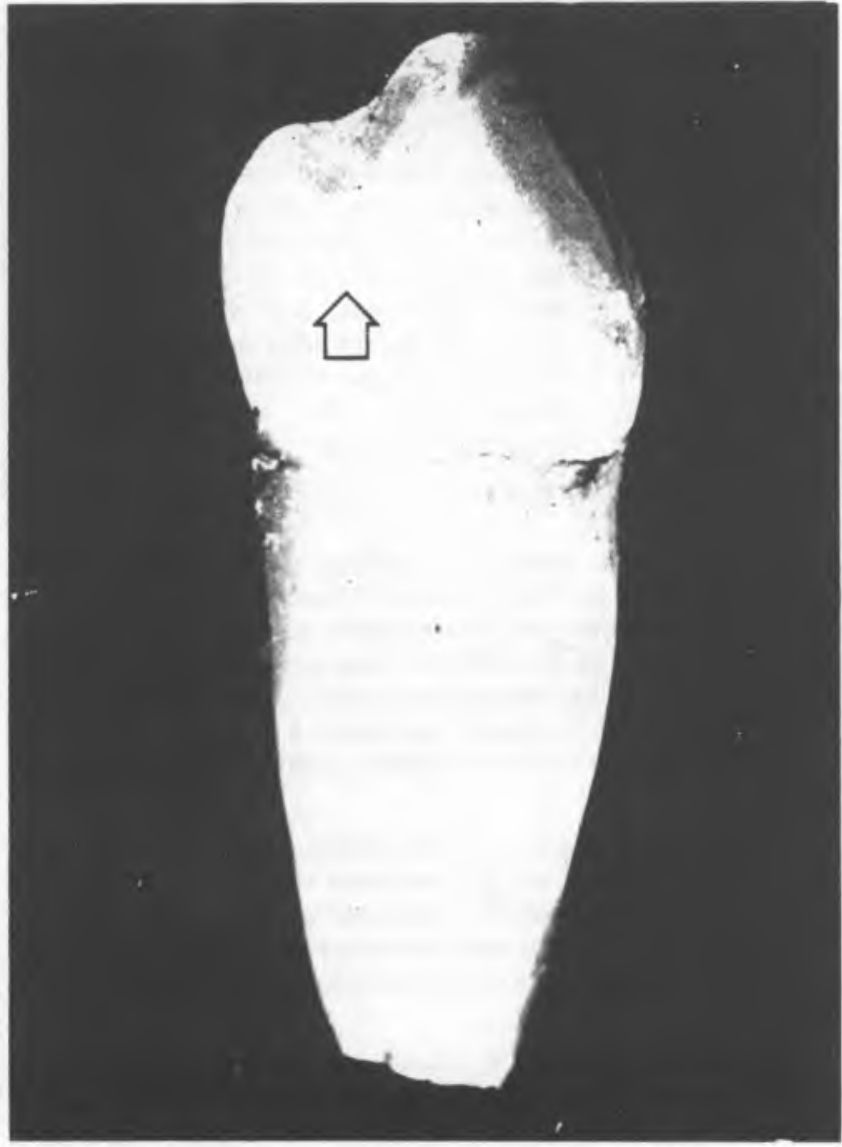

Este dente mostra uma subsuperficie, regiào parcialmente desmineralizada (seta), referida normalmente por mancha branca número de molares permanentes faltando em crianças de idades compreendidas entre os 12 e os 15 anos em comunidades dispondo de água potável contendo $1 \mathrm{ppm}$ de fluoreto era inferior em 75 a $95 \%$ do que nas crianças provenientes de comunidades cuja água potável só continha cerca de $0,1 \mathrm{ppm}$ de fluoreto.

Beber àgua fluoretada é, em primeiro lugar, de valor para os jovens, cujos dentes estāo a calcificar e a matutar. Embora em menor escala, também traz beneficios para os adultos, reduzindo a cárie.

$\mathrm{O}$ tratamento da água potável com fluoreto também ajuda a proteger os dentes a um custo relativamente baixo. Ainda uma outra vantagem da água fluoretada é que, tal como os dentifricos contendo fluoreto; permite a uma pessoa aumentar a sua resistência à cárie sem que para isso tenha de fazer um esforço consciente.

Embora algumas pessoas pensem no fluoreto como sendo exclusivamente um aditivo artificial, o facto è que se encontra presente em toda a água natural, bem como em diversos alimentos. As principais fontes alimentares de fluoreto incluem diversos tipos de peixe e o chá.

O tratamento da água potável com fluoreto continua a ter opositores, que se queixam de que é uma "medicação forçada" e acham que deveriam ter a liberdade de não beberem água tratada com fluoreto se assim o desejarem.

Através dos anos, as pessoas que se opōem ao tratamento da água com fluoreto têm alegado que causa cancro, doenças cardiacas, defeitos de nascença, alergias, doenças renais, mongolismo, desenvolvimento ósseo defeituoso, esterilidade e até que faz cair os dentes.

Por outro lado, um estudo levado a cabo pelo Organização Mundial de Saúde concluiu que não existem provas aceitáveis de que a água fluoretada, aos niveis recomendados cause quaisquer efeitos adversos. "A sobrevivên. cia continuada da noção de que o tratamento da água com fluoreto é um 'assunto controverso' representa, na nossa geração, um dos maiores triunfos do mito sobre a ciência."

No entanto, alguns cientistas dentários avisam de que o tratamento da água com fluoreto não deve ser considerado como um caso encerrado. Edward A. Sweeney, professor associado de odontologia pediátrica da Escola de Medicina Dentária de Harvard, diz que "Não é justo, nem cientificamente honesto, pôr de lado sem mais nem menos todas as criticas feitas à adição de fluoreto à água. Por exemplo, é admissivel que, se forem devidamente investigadas, se possa demonstrar que algumas alergias estão associadas ao uso de fluoreto. No entanto, até à data os criticos da utilização de fluoreto não substanciaram por meio de métodos rigorosos as suas alegações de que o fluoreto causa alergias ou quaisquer outras desordens.n

\section{COMO É QUE O FLUORETO COMBATE A CÁRIE?}

Quase ninguèm duvida de que o fluoreto combate a cárie. o fluoreto actua, em parte, convertendo numa pequena extensão o principal constituinte do esmalte, a hidroxiapatite, em fluorapatite. A reacção é a seguinte:

$$
\mathrm{Ca}_{10}\left(\mathrm{PO}_{4}\right)_{6}(\mathrm{OH})_{2}+2 \mathrm{~F} \longrightarrow \mathrm{Ca}_{10}\left(\mathrm{PO}_{4}\right)_{6} \mathrm{~F}_{2}+2 \mathrm{OH}
$$

O fluoreto reduz a cárie em parte porque o seu ião se encaixa melhor na rede cristalina da apatite do que o ião hidroxilo, que é ligeiramente maior. Assim, o fluoreto forma um cristal mais estável, menos solúvel em ácido. A solubilidade da fluorapatite no ácido láctico é de apenas $1 / 100$ da da hidroxiapatite.

Segundo alguns cientistas, a fluorapatite pode preencher vazios ou reparar defeitos no esmalte dos dentes, tornando-o mais resistente aos ácidos. Pensa-se também que a formação de fluorapatite elimina diversas impurezas do esmalte, entre as quais o carbonato, que é relativamente solúvel em ácido.

De acordo com uma outra teoria, o ião fluoreto facilita a remineralização do esmalte com hidroxiapatite, fazendo com 


\section{Muitas hipóteses têm sido apresentadas para explicar como é que a cárie ataca os dentes}

Ao longo dos séculos, numerosas hipóteses têm sido apresentadas para explicar as causas da cárie. A luz dos conhecimentos actuais, algumas dessas noçōes parecem ridiculas, enquanto que outras fornecem respostas para pelo menos uma parte do quebra-cabeças. Hoje em dia há uma teoria que é geralmente aceite.

No século VII a.C., os Assírios acreditavam que era um verme que causava as cavidades dos dentes. Surpreendentemente, esta ideia persistiu nalguns quadrantes até cerca de 1850 . A sua aceitaçâo pode ter em parte resultado do facto de por vezes se terem encontrado nas cavidades dentais vermes provenientes de alimentos infestados. Além disso, muitas pessoas pensavam que, se os vermes podem abrir buracos na madeira, deviam poder fazer o mesmo aos dentes.

No tempo dos Gregos e dos Romanos, muitas pessoas pensavam que a cárie era causada por humores malignos ganhando ascendente sobre humores benignos nos dentes. Hipócrates concluiu que as cavidades eram causadas "pela estagnação de sucos depravadosı nos dentes. Galeno pretendia que a cárie começava no interior do dente e era causada por uma condição anormal do sangue, resultando em "humores acridos corrosivos".

Entre o final do século XVIII e meados do século XIX, uma ideia muito disseminada era a de que a cárie começava no ir.terior de um dente, sendo assim análoga à gangrena óssea.

Em 1819, Parmly sugeriu que a cárie era causada quando o esmalte era atacado por um "agente quimicon externo. Acreditava ele que esse composto quimico destruidor, que não identificou, era formado pela putrefacção dos alimentos. Cerca de 1830 outros investigadores descobriram que os ácidos sulfúrico e nitrico podiam decompor o esmalte e a dentina.

No entanto, não foi com Parmly que surgiu o conceito de que a dieta está envolvida na cárie. Nos tempos antigos, Aristóteles notou que, quando as pessoas comiam figos maduros, doces, e algum pedaço do fruto pegado aos dentes entrava em putrefacção, os dentes apresentavam maior tendência para a cárie.

Cerca de 1845, um médico de Dresden, Ficinus, descobriu vários micro-organismos em material removido de cavidades dentais. Ficinus sugeriu que estas bactérias, a que chamou denticolae, eram as causadoras da desintegração do esmalte, mas năo explicou como isso acontecia.

Um dentista britânico, W. K. Bridgeman, fascinado pelas experiências de Michael Faraday, propôs em 1861 uma hipótese eléctica da cárie. Acreditava que na boca existia o equivalente de uma pilha, em que os dentes são elćtrodos e a saliva o electólito, concluindo que era a passagem de electricidade na boca que causava a desintegraçāo dos dentes.

Em 1890, Willoughby D. Miller, um dentista americano, publicou o seu tratado clássico "The Microorganisms of the Human Mouthn, em que delineou a teoria da cárie que é. ainda hoje, a mais largamente aceite. Miller concluiu, como resultado de extensa experimentação, que a cárie é causada quando ácidos, com o ácido láctico, na superfi- cie dos dentes desmineralizam 0 esmalte por remoção de cálcio. Dizia ele que estes áciaos não provêm oia saliva (como outros pressupunham), sendo antes produzidos pelas bactérias a partir de açúcares e outros carbohidratos fermentáveis das particulas alimentares aderentes ais dentes.

Uma outra hipótese, apresentada em 1944, sugeria que na cárie a etapa inicial não é a decomposiçẫo de compostos inorgânicos, como defendiam Miller e outros, mas sim a destruiçāo de proteina por enzimas proteolíticos das bactérias. Estas proteinas, que constituem menos de $2 \%$ em peso do esmalte humano, formam uma delicada rede que rodeia os cristais de hidroxiapatite do esmalte. Alegava-se ainda que a dissoluçăo subsequente dos sais inorgânicos do esmalte pelos ácidos era promovida por essa hidrólise de proteina.

Outra hipótese, proposta em 1955, é a de que o esmalte é desmineralizado quando o cálcio é removido sob a forma de quelatos. Substâncias como o lactato, o citrato e aminoácidos, que estão presentes na saliva e na placa, podem formar quelatos. De acordo com esta hipótese, a cárie pode ocorrer sem que haja formação de ácido, porque a formação de quelatos pode dar-se a $\mathrm{pH}$ alcalino ou neutro.

Muito provavelmente nos anos vindouros serão ainda propostas outras ideias para explicar a cárie. No entanto, a sua validade certamente sera posta à prova, já que a maioria dos cientistas dentários crê que hoje em dia se conhece bem a maior parte dos aspectos do processo da cárie. que esta precipite a concentraçōes mais baixas de iöes cálcio e fosfato.

O fluoreto também pode evitar a cárie matando ou interfe rindo com o crescimento e metabolismo de bactérias da placa capazes de formar ácido, reduzindo a conversāo de açúcares em ácidos. Um grupo de pesquisadores propôs uma tese segundo a qual o fluoreto interfere com o transporte de açúcar para as células bacterianas.

Além disso, o fluoreto pode auxiliar a combater a cárie inibindo a formaçāo de polissacaridos que promovem a adesão de bactérias às superficies do esmalte. Ainda não foi determinado se são ou não válidos este e outros mecanismos propostos para explicar a acçāo do fluoreto.

É claro que o dentes podem ser tratados com fluoreto sem que seja necessário o uso de água tratada com fluoreto. Muitas pastas de dentes contêm fluoretos, em geral na concentração de $0,1 \%$, quer como fluoreto estanoso, monofluorofosfato de sódio ou fluoreto de sódio.

Os fluoretos também podem ser periodicamente aplicados nos dentes, em concentraçâo relativamente elevada (em geral de 1 a $2 \%$ ) como soluçōes aquosas de fluoreto de sódio, fluoreto estanoso ou fluorofosfato acidulado.

Esse tratamento, se for efectuado uma ou duas vezes por ano, pode reduzir de 30 a $\mathbf{4 0} \%$ a cárie entre crianças e adultos jovens. O tratamento, embora relativamente dispendioso por ter de ser feito por profissionais dentários, é de especial utilidade em comunidades que nāo dispōem de água potável tratada com fluoreto.

Igualmente eficazes nessas comunidades são os programas de lavagem da boca que em geral são levados a cabo nas escolas. Um estudo realizado demonstrou que a cárie pode ser reduzida de $50 \%$ em crianças que diariamente e durante cerca de 1 minuto lavam a boca com uma soluçäo contendo $0,02 \%$ de fluoreto.

Desde 1975 que o NIDR, através do seu Programa Nacional de Cárie, tem levado a efeito nas escolas programas de lavagem da boca. Mais de 8 milhöes de crianças em idade escolar sāo abrangidas por esses programas, verificando-se que há uma redução da cárie, em média, de cerca de $35 \%$ nessas crianças, 
que uma vez por semana utilizam uma solução contendo $0,09 \%$ de fluoreto para lavar a boca.

Para combater a cárie também existem comprimidos de fluoreto, que podem ser mastigados e engolidos. A cárie é, em média, reduzida de cerca de $35 \%$ nas crianças que diariamente tomam um comprimido contendo $1 \mathrm{mg}$ de fluoreto.

A Abcor, de Cambridge, Massachussets, tem estado a testar um comprimido contendo fluoreto de sódio, microencapsulado em etil celulose. Libertando o fluoreto no organismo ao longo de um periodo de 18 a 24 horas, este comprimido mantem na saliva niveis elevados de fluoreto por periodos mais prolongados do que os comprimidos convencionais de fluoreto.

Um outor método para aplicaçāo de fluoreto nos dentes envolve o uso de um gel com $0,5 \%$ de fluoreto, contido num bocal plástico feito sob medida. No entanto, este método apresenta algumas desvantagens importantes. Cada criança pode ter de usar um novo bocal tảo frequentemente como de seis em seis meses. O uso do gel requer uma supervisão cuidada e é relativamente dispendioso, demorado e sujo.

Recentemente têm sido desenvolvidas unidades que libertam lentamente fluoreto na vizinhança dos dentes Istas unidades, desenvolvidas por Donald R. Cowsar e Danny $\mathbf{H}$. Lewis, do Southern Research Institute de Birming ham, Alabama, são em geral ligadas à superfície da mucosa bocal que toca num molar superior. Essas unidades podem libertar continuamente até $0,1 \mathrm{mg}$ de fluoreto por dia durante um periodo de seis meses, e sāo essencialmente constituidas por um núcleo central de particulas de fluoreto de sódio dispersas num copolimetro de metacrilato hidroxietílico $e$ metacrilato de metilo. O núcleo encontra-se dentro de uma membrana feita de mesmo copolimero, que controla a velo. cidade de libertação do fluoreto de acordo com a espessura $e$ a permeabilidade da membrana. Estas unidades começaram a ser testadas em 15 pessoas em Outubro de 1979, no NIDR

Alguns investigadores têm estado a estudar diversos métodos que permitam aumentar a quantidade de fluoreto adquirida pelo esmalte dentário, No NBS, Walter E. Brown e Laurence C. Chow investigaram a utilização de uma solução contendo ácido fosfórico e saturada com hidrogenofosfato de cálcio $\left(\mathrm{CaHPO}_{4} \cdot 2 \mathrm{H}_{2} \mathrm{O}\right)$ para converter parte da superficie do esmalte neste composto de cálcio. Através do seu método conseguiram quase duplicar a quantidade de fluoreto perma. nentemente incorporado no esmalte de dentes de ratos. Brown explica que o fluoreto reage mais rapidamente com hidrogenofosfato de cálcio dihidratado do que com o esmalte não tratado.

Os cientistas continuam à procura de outros iōes, para além do fluoreto, que tambèm possam melhorar a resistência dos dentes à cárie. Alguns estudos epidemológicos sugerem que o molibdénio e o vanádio podem combater a cárie, mas os dados existentes săo ainda muito limitados.

Experiências em animais também sugerem que metais taís como o estrôncio, o molibdério, o vanádio, o lítio, o bário e o boro podem sinergizar a acçāo do fluoreto no combate à cárie. Diz um pesquisador dentário que "Muitos dos dados ainda săo equivocos e será necessário tempo para os destrinçar. No entanto, a combinação apropriada de metais deve aumentar para além dos niveis actuais a resistência dos dentes à cáriè.."

\section{VACINAS ANTICÁRIE}

Um dos temas mais empolgantes dos últimos anos tem sido a pesquisa de vacinas para eliminar a cárie. Se as vacinas podem proteger os seres humanos contra doenças bacterianas como a difteria e o tétano, nāo poderá ser desenvolvida uma vacina para os proteger contra a cárie, outra doenca bacteriana?

No inicio e nos meados do anos 70 , ratos, hamsters ou macacos foram injectados quer com células vivas quer com células mortas de S. mutans. Em quase todos os casos os animais desenvolveram menos cavidades do que animais nāo tra. tados, quando ambos foram mais tarde alimentados com uma dieta rica em açúcar.
Tipicamente, os animais foram injectados com a vacina próximo das glândulas salivares, de modo a que produzisse o anticorpo secretor de imunoglobulina $A(\lg A)$ que pudesse combater eficazmente o S. mutans. Como faz notar James P. Carlos, director associado do NIDR, na luta contra a cárie é importante produzir a forma de $\lg A$ que está presente na saliva, em vez do tipo presente no sangue (soro $\lg A$ ), visto que o esmalte não entra em contacto com a corrente sanguinea.

Ainda não se sabe bem como é que o anticorpo secretor de IgA interfere com a acçāo do $\mathrm{S}$. mutans. Alguns cientistas crêem que impede a aderência das bactèrias aos dentes ou que inibe a sua colonizaçăo nos dentes. Outros cientistas pensam que o anticorpo pode atacar directamente o S. mutans.

Diversos grupos de pesquisadores testaram em animais vacinas baseadas no $\mathrm{S}$. mutans. Por exemplo, em 1972, William H. Bowen, então no Colègio Real dos Cirurgiōes, de Londres, $\theta$ presentemente chefe do ramo de prevenção e pesquisa da cárie do NIDR, descreveu os resultados de um estudo feito em cinco macacos, aos quais injectou S. mutans. Passados cinco anos após terem sido injectados, os animais não tinham desen. volvido cavidades nos dentes. Por outro lado, cinco macacos que nảo receberam a vacina mas foram alimentados com a mesma dieta desenvolveram 64 cavidades. Resultados prometedores análogos foram obtidos em estudos com animais em que se utilizou S. mutans morto quer com formaldeido quer pelo calor.

Alguns grupos americanos realizaram experiências muito limitadas com vacinas anticárie em seres humanos, para testar a sua segurança e determinar se produzem os anticorpos secretores desejados. Em 1978, Jiri Mestecky, Jerry R. McGhee e colaboradores, do Centro Médico da Universidade de Alabama, descreveram os resultados de testes em que, uma vez por dia durante catorze dias, quatro adultos tomaram cápsulas con. tendo S. mutans morto. Estes investigadores verificaram que, passada uma semana, na saliva destes voluntários estava presente um anticorpo IgA do $S$. mutans, além de que o processo nảo provocou efeitos nocivos. No entanto, os perquisadores não determinaram se o método utilizado reduz a cárie em seres humanos.

No NIDR, na Universidade Estadual de Nova lorque, Buffa. lo, e noutros locais têm sido também testadas em seres huma. nos vacinas orais contra a cárie.

Alguns cientistas estão apreensivos quanto à segurança da utilizaçăo de uma vacina inteiramente baseada em $\mathrm{S}$. mutans vivo ou morto. Tal como aconteceu com outras vacinas estreptocócicas, algumas pessoas que recebem uma vacina daquele tipo poderão vir a sofrer de afecçôes cardiacas.

Diz um observador, "A administração de uma vacina contra o tétano, por exemplo, embora possa provocar alguns efeitos secundários adversos, pode justificar-se porque o tétano cons. titui uma ameaça à vida. Já tratar alguém contra a cárie com uma vacina potencialmente perigosa não parece ser uma ideia tảo boa, visto que a cárie nunca é letal."

Para uso em seres humanos os pesquisadores favorecem decididamente uma vacina anticárie para administração por via oral, em vez de por injecçäo próximo das glândulas salivares, a qual pode causar inflamação considerável.

Devido à preocupação sobre a segurança da utilização de uma vacina só constituída por células, alguns investigadores procuram uma vacina que combata não só o $\mathrm{S}$. mutans mas também um enzima por este produzido, a glucosiltransferase (GTF). Se este enzima, que está envolvido no processo de polimerização da glucose derivado do açúcar para dar gluca. nos, for inactivado, os glucanos não se formam e as bactérias năo podem aderir à superficie do esmalte. A grande vantagem potencial de uma vacina baseada na GTF em vez de no $\mathrm{S}$. mutans é que o enzima é mais simples e mais puro, sendo assim menos apto a produzir efeitos colaterais indesejáveis.

Em 1977, Martin A. Taubman e Daniel J. Smith, do Centro Dentário Forsyth, descreveram experiências em que injectaram diversas fracçōes de GTF derivadas do S. mutans perto das glândulas salivares de ratos. Com resultado, estes animais desenvolveram até menos de $50 \%$ de cavidades do que ratos 
alimentados com a mesma dieta mas que não foram injectados. Também foram obtidos bons resultados pelo uso de GTF em hamsters e macacos.

Em 1979 os cientistas do Centro Dentário Forsyth relata. ram experiências em que GTF foi ministrada a hamsters por via oral, em vez de por meio de injecção, e os resultados foram igualmente prometedores. Espera-se para breve a realização de testes com uma vacina GTF em seres humanos.

Alguns peritos têm dúvidas quanto à capacidade dos cientistas para desenvolverem uma vacina anticárie segura $e$ potente para seres humanos. No entanto, outros observadores sentem-se mais confiantes.

Irwin Mandel diz que "apesar de toda a expectativa criada pelas últimas descobertas em estudos com animais, há muito para aprender antes que se possa ser optimista sobre uma vacina anticárie para seres humanos. É dificil prever quando é que de facto poderá ser produzida uma vacina simultaneamente segura e eficaz.n

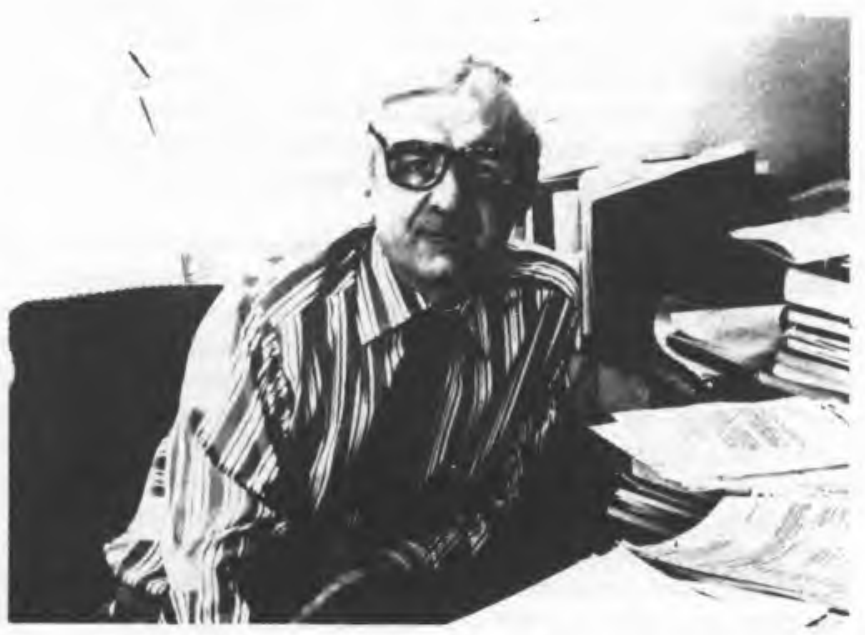

BOWEN: Depois da injecção da vacina de S. Mutans, cinco macacos não desen volveram cavidades dentarias durante cinco anos

William Bowen, do NIDR, afirma que "São excelentes as perpectivas de desenvolvimento de uma vacina anticárie para seres humanos, mas será preciso ter cautela."

James H. Shaw, professor da Escola de Medicina Dentária de Harvard, comenta: "Não parece estar muito próxima a imunização de seres humanos contra a cárie. No entanto, o recurso a vacinas pode vir a tornar-se muito valioso no futuro."

Segundo Solon A. Ellison, professor de medicina dentária na Universidade de Colúmbia, "Pode ser desenvolvida uma vacina anticárie eficaz para uso em larga escala em seres humanos. No entanto, essa vacina, tal como outras, comportará riscos. Mas estes riscos, creio eu, serão reduzidos."

Uma outra via para o controlo da cárie envolve o recurso a bactérias muito semelhantes ao $\mathrm{S}$. mutans mas que não convertem açúcar em ácido capaz de destruir o esmalte. Em 1977, Jeffrey D. Hillman, do Centro Dentário Forsyth, desenvolveu um mutante do $\mathrm{S}$. mutans que, ao contrário da estirpe original, contém pouca ou nenhuma lacticodesidrogenase, a qual está envolvida na formação de ácido láctico a partir da sacarose.

Quando se introduz o mutante na boca de ratos assépticos e estes são depois alimentados com uma dieta rica em açúcar, verifica-se que se desenvolvem muito poucas cavidades. Os estudos realizados mostram também que o mutante pode competir eficientemente com a estirpe original na colonização da superficie do esmalte, podendo nalguns casos excluir quase totalmente a extirpe original.

John Hein, do Centro Dentário Forsyth, refere: "As actuais descobertas em animais são muito encorajadoras. Sugerem que um modo de reduzir a cárie seria a pré-infecção de crianças com um mutante não virulento do $\mathrm{S}$. mutans, antes de ser adquirido o $\mathrm{S}$. mutans virulento. No entanto, antes que este método possa ser experimentado em seres humanos, deve ser feita mais pesquisa nesta área.n

Numa outra via para combater a cárie, experiências com hamsters mostraram que o enzima dextranase é muito eficaz na degradação de glucanos e, portanto, no impedimento da adesāo do $\mathrm{S}$. mutans ao esmalte.

EStes resultados encorajadores levaram os investigadores a testar dextranase num grupo de crianças porto-riquenhas, aplicando-a aos seus dentes sob a forma de um gel contido num bocal feito sob medida. James Carlos, do NIDR, diz que os resultados foram muito desapontadores. Os glucanos produ. zidos nos seres humanos são muito mais complexos do que os produzidos em hamsters e assim, nos seres humanos, a dextranase apenas decompōe uma pequena percentagem dos glucanos nos dentes. Além disso, nos testes com hamsters os animais foram continuamente expostos ao enzima, o que é impraticàvel em seres humanos.

\section{SUBSTITUTOS DO AÇÜCAR}

Uma vez que o açúcar desempenha um papel importante na cárie, os cientistas estão a investigar outros edulcorantes. Existem já muitos adoçantes alternativos - calóricos ou não-calóricos. No entanto, até muito recentemente não se deu grande atençảo à possibilidade de os edulcorantes substituintes do açúcar serem armas eficazes contra a cárie. James Shaw, de Harvard, diz que "Prevejo que, na próxima década, os industriais de produtos alimentares promovam activamente muitos produtos novos não contendo açúcar pois têm menos probabilidades de causar cáries do que os produtos convencionais.n

Entre os edulcorantes calóricos não contendo açúcar encontram-se os álcoois polihidricos sorbitol, manitol e xilitol, que podem ser convertidos em ácido pelo S. mutans. no entanto, como essa conversão é lenta, o tampão presente na saliva neutraliza o ácido quase tão rapidamente como ele se forma. Assim o pH da placa diminui pouco e nâo é provável a cárie.

Há alguns anos, e principalmente como resultado de pesquisa feita na Finlândia, deu-se grande interesse ao xilitol como adoçante para produtos alimentares. Este composto é quase tão doce como a sacarose e duas vezes mais doce do que o sorbitol ou o manitol.

No inicio de 1977, a Wm. Wrigley Jr. Co. começou a comer. cializar uma pastilha elástica contendo xilitol. Embora a Wrigley fizesse propaganda do facto de o seu produto não conter açúcar, nunca afirmou que tinha menos probabilidades de causar cárie do que as pastilhas elásticas vulgares (embora esta fosse a implicação óbvia). Nos finais de 1978, o Centro de Pesquisa de Huntingdon, em Inglaterra, concluiu que o xilitol pode causar cancro da bexiga e cancro adrenal em ratos. Devido à publicidade adversa provocada pelo relatório, a Wrigley deixou de usar xilitol nessas pastilhas elásticas, substituindo-o por uma combinação de sorbitol e manitol. Além deste produto da Wrigley, existem no mercado duas outras pastilhas elásticas sem açúcar, que contêm sorbitol e manitol como edulcorantes.

Os três polióis referidos, quando consumidos em grandes quantidades, podem causar diarreia, o que limita o seu uso em larga escala como substitutos da sacarose.

Há cerca de dez anos, a G. D. Searle \& Co. desenvolveu o substituto do açúcar aspártamo éster metilico da L-aspartil-L-fenilalanina), um dipeptido cerca de 180 vezes mais doce do que a sacarose. A Food \& Drug Administration aprovou, em 1974, o uso de aspártamo em alimentos; no entanto, um ano depois, a FDA anulou essa aprovaçāo em consequência de terem surgido dúvidas quanto à inocuidade do produto. Continuam a ser feitos testes para determinar se o aspártamo pode ser utilizado sem perigo para a saúde e muitos observadores estão opti nistas quanto à sua eventual aprovação como aditivo alimentar.

Também tem interesse um grupo de edulcorantes quimicamente derivados de compostos presentes na casca das 


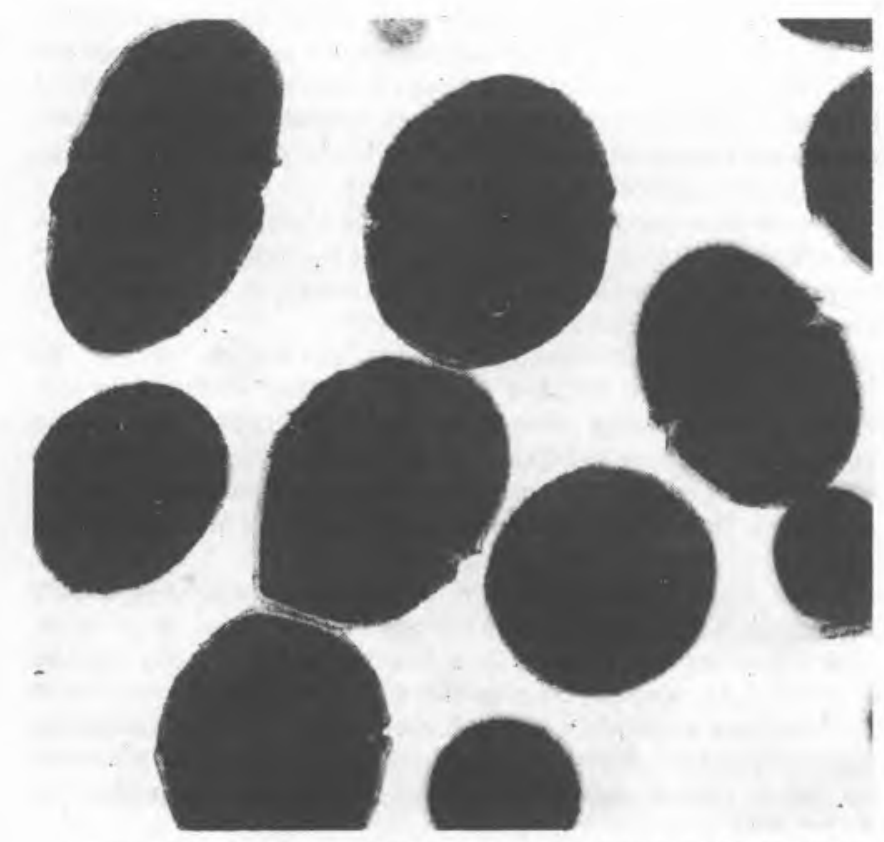

S. mutans, totografada por microscopia electrónica de transmissâo, è a principal bactéria causadora da decomposição dentária

laranjas e das toranjas. Inicialmente desenvolvidos por cientistas do Departamento de Agricultura dos E.U.A., esses edulcorantes são conhecidos como dihidrocalconas. Entre estes compostos estão a naringina dihidrocalcona ( 100 vezes mais doce que a sacarose) e a neohesperidina dihidrocalcona (cerca de 2000 vezes mais doce que a sacarose). No entanto, estes compostos têm um sabor doce invulgarmente persistente que pode tornar indesejável a sua utilização em muitos produtos alimentares.

Em parte devido a esta desvantagem, em 1976, a Dynapol Corporation de Palo Alto, Califórnia, foi contratada pelo NIDR para sintetizar análogos da neohesperidina dihidrocalcona. Até à data, a Dynapol testou mais de $\mathbf{4 0}$ análogos, mas nenhum deles apresenta o rápido desaparecimento do sabor doce que em geral se deseja ao se utilizar um substituto da sacarose.

Presentemente o único edulcorante não-calórico no mercado americano é a sacarina, que não é convertida em ácido pelas bactérias da boca e que é cerca de 300 vezes mais doce do que a sacarose. Embora largamente usado, a utilização futura deste composto mantém-se duvidosa devido a relatórios de que, quando ministrada em largas doses, causa cancro da bexiga em ratos.

Outro edulcorante não -calórico que também não provoca cárie é o ciclamato, cerca de 30 vezes mais doce que a sacarose e que foi primeiramente comercializado nos E.U.A. pelos labo ratórios Abbott, em 1950. Em 1969 a FDA baniu o seu uso como aditivo alimentar devido a relatórios segundos os quais, quando ministrado em largas doses a ratos, causa cancro da bexiga.

Devido ao facto de a utilização de substitutos do açúcar quase nunca permitir que se obtenham produtos alimentares com as mesmas propriedades do que os que contêm açúcar, os produtores de alimentos preparados contendo substitutos do açúcar têm de defrontar-se com o problema da aceitação pelo público consumidor. Por outro lado, o enorme sucesso comercial dos refrigerantes para dietas indica que as pessoas aceitarão produtos de sabor menos atraente desde que tenham outra caracteristica compensadora.

William Bowen, do NIDR, diz que "Hoje em dia a maioria das pessoas compra alimentos contendo substituintes do açúcar porque quer perder peso. É claro que ficaremos entusiasmados se esses mesmos alimentos também ajudarem a reduzir a cárie. Tendo em conta a crescente preocupação do público com o problema da cárie, acredito que futuramente muitas pessoas comprarão uma gama mais vasta de alimentos contendo substituintes do açúcar para aumentarem a protecção dos seus dentes contra a cárie.n

$\mathrm{Na}$ batalha contra a cárie, alguns investigadores têm explorado o uso de antissépticos que destorem o $\mathrm{S}$. mutans, como a clorohexidina e a alexidina.

A clorohexidina tem tido especial interesse, pois é retida na boca durante várias horas, aderindo fortemente às superficies dos dentes e membranas mucosas orais, e, ao contrário de alguns outros antissépticos, não é rapidamente levada pela saliva.

Há alguns anos os cientistas esperavam que a clorohexidina pudesse vir a ser útil no combate à cárie em seres humanos, pois experiências realizadas com animais mostraram ter havido redução da cárie. No entanto, quando o composto foi testado em dentífricos e loçōes orais, não correspondeu às expectativas. Além disso, quando usada por periodos prolongados a clorohexidina provocou a descoloração dos dentes e algumas pessoas experimentaram alterações no paladar.

Vários investigadores têm testado antibióticos para des. truir o S. mutans. Para que este método tivesse aplicação prática, os antibióticos teriam de ter pouco valor no tratamento de outras doenças importantes. Por exemplo, a penicilina não poderia ser utilizada durante um periodo prolongado para controlar a cárie porque eventualmente as bactérias se poderiam tornar resistentes a ela, deixando o antibiótico de ser tão eficaz no tratamento de outras doenças.

Os investigadores que procuram lutar contra a cárie têm investigado o uso de antibióticos menos populares do que a penicilina, como a vancomicina, a kanamicina e a nidamicina. No entanto, os estudos feitos nesta área têm avançado muito lentamente. Os cientistas estão preocupados com a possibi. lidade de que o uso de um antibiótico por periodos prolongados possa fazer com que o S. mutans se torne resistente a ele, alem de que o antibiótico pode destruir bactérias benéficas existentes na boca.

\section{POLIMETROS PROTECTORES DOS DENTES}

Crescente atenção tem incidido no uso de substâncias plásticas para aumentar a resistência dos dentes à cárie, protegendo as superficies de mastigação (particularmente as suas concavidades e fissuras) de bactérias e partículas dos alimentos. Estas substâncias são aplicadas aos dentes de modo semelhante a um verniz incolor para as unhas.

As primeiras substâncias estudadas para este fim foram os cianoacrilatos, como o metil-2-cianoacrilato. Trata-se de liqui-

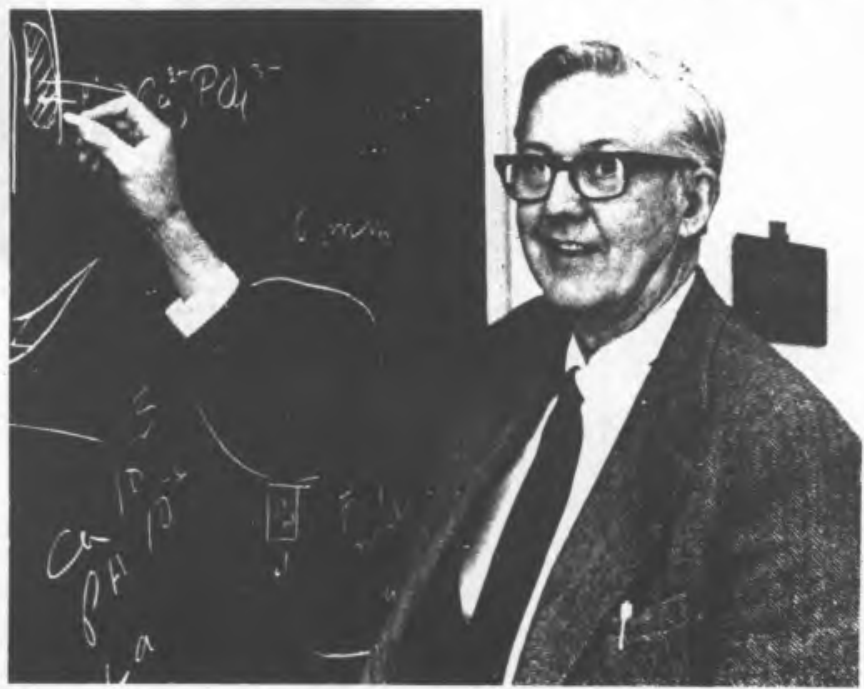

BROWN: Tratamento do esmalte de ratos com fosfato dicálcico dihidrato aumenta a fixacầo de fluoreto 
dos pouco viscosos que polimerizam formando sólidos duros. No entanto, a camada resultante da sua aplicação é gradual mente decomposta na boca por hidrólise, ou é gasta pela mas. tigação, pelo que a camada protectora deve ser substituida cada seis meses.

Actualmente o polimero mais usado para selar os dentes contra a cárie é obtido por reacção de metacrilato de glicidilo e bisfenol A. Desenvolvido por Rafael L. Bowen, do NBS, o produto de adição resultante polimeriza, formando uma resina dura.

Este material, vulgarmente conhecido como Bis-GMA, è aplicado nos dentes depois de estes terem sido tratados com um ácido (usualmente ácido fosfórico) para melhorar a sua aderência ao esmalte. Num destes produtos (Delton. fabricado pela Johnson \& Johnson) a polimerização é feita por um catalisador. Um outro produto (Nuva-Seal, da L. D. Caulk Co.) é polimerizado por um catalizador activado por luz ultra-violeta. $O$ Delton começa a polimerizar e a ficar mais espesso antes de ser aplicado, enquanto que o Nuva-Seal não começa a polimerizar antes de ser aplicado nos dentes é exposto à luz ultra-violeta, o que torna mais fácil o seu uso. Substâncias como o Bis-GMA protegem as concavidades e fissuras dos dentes contra a cárie, zonas essas que são as menos auxiliadas pela água tratada com fluoreto.

No entanto, o recurso a polimetros para protecção dos dentes contra a cárie também tem algumas desvantagens. Trata-se de um método dispendioso, pois o produto só pode ser aplicado por um dentista, podendo o processo demorar meia hora ou mais. Além disso, os dentes tratados por este método devem ser inspeccionados periodicamente para assegurar que a camada protectora se encontra intacta.

Irwin Mandel diz que "Do ponto de vista clinico, o uso de substâncias plásticas é eficiente, mas, dadas as presentes técnicas de aplicação e o tempo de retenção do produto, os custos podem ultrapassar os beneficios."

Herschel S. Horowitz, um dos chefes de secção do Programa nacional de Cárie do NIDR, declara: "O custo da aplicação dos polimeros poderia ser muito reduzido, e o seu uso consequentemente alargado, se o trabalho pudesse ser feito não só por dentistas mas também por paraprofissionais dentários. De facto a aplicação correcta destes materiais não é assim tão dificil.n

Em muitos laboratórios continua o esforço para se encontrarem melhores processos para combater a cárie. Diz John W. Hein, director do Centro Dentário Forsyth: “Devido ao seu esforço determinado, os cientistas desenvolveram novos pro. cessos para prevenir a cárie. À medida que formos aplicando estes métodos, há uma boa probabilidade de que nas próximas décadas a cárie deixe de ser um dos principais problemas de saúde.n

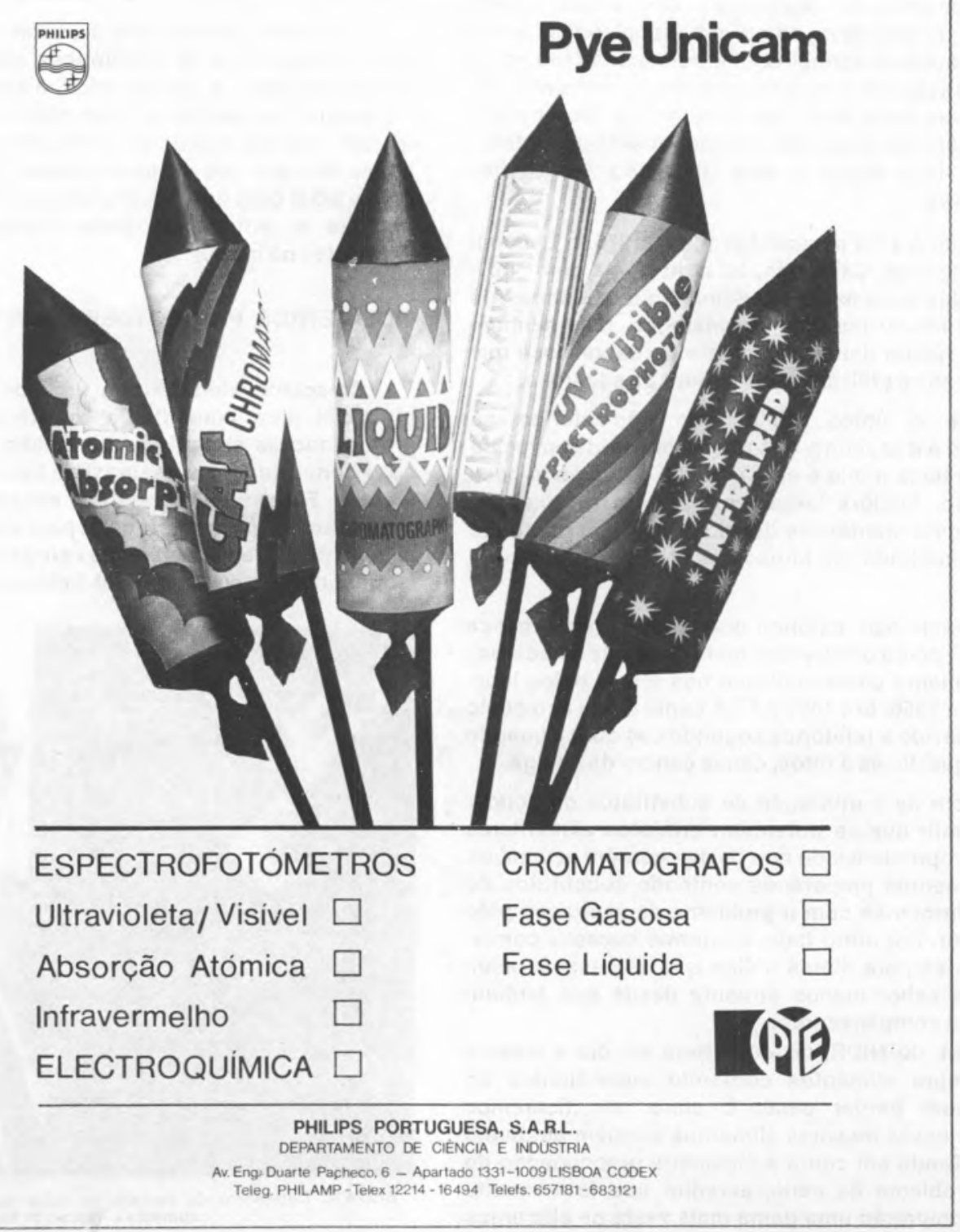

